\title{
Use of near-infrared spectroscopy for prediction of chemical composition of Tifton 85 grass
}

\section{Uso da espectroscopia de infravermelho próximo para a predição da composição química de capim Tifton 85}

\author{
Camila Cano Serafim ${ }^{1 *}$; Geisi Loures Guerra²; Ivone Yurika Mizubutii ${ }^{3}$ Filipe \\ Alexandre Boscaro de Castro4; Odimári Pricila Prado-Calixto5; Sandra Galbeiro4; \\ Angela Rocio Poveda Parra4; Valter Harry Bumbieris Junior ${ }^{5}$; Simone Fernanda \\ Nedel Pértile ${ }^{6}$; Fabíola Cristine de Almeida Rego ${ }^{6}$
}

\section{Highlights}

Mathematical modeling can be applied successfully in the evaluation of forage plants. Prediction models can replace conventional chemical analyses for Tifton 85 grass.

Crude protein content can be predicted with excellent accuracy using NIRS technology.

\begin{abstract}
The reduction in the quality, consumption, and digestibility of forage can cause a decrease in animal performance, resulting in losses to the rural producer. Thus, it is important to monitor these characteristics in forage plants to devise strategies or practices that optimize production systems. The aim of this study was to develop and validate prediction models using near-infrared spectroscopy (NIRS) to determine the chemical composition of Tifton 85 grass. Samples of green grass, its morphological structures (whole plant, leaf blade, stem + sheath, and senescent material) and hay, totaling 105 samples were used. Conventional chemical analysis was performed to determine the content of oven-dried samples (ODS), mineral matter $(\mathrm{MM})$, crude protein $(\mathrm{CP})$, neutral detergent fiber (NDF), acid detergent fiber (ADF), acid detergent lignin $(A D L)$, cellulose (CEL), hemicellulose (HEM), and in vitro dry matter digestibility (IVDMD). Subsequently, all the samples were scanned using a Vis-NIR spectrometer to collect spectral data. Principal component analysis (PCA) was applied to the data set, and modified partial least squares was used to correlate reference

1 Student, Doctoral Course of the Graduate Program in Animal Science, State University of Londrina, UEL, Londrina, PR, Brazil. E-mail: camilacanoserafim@hotmail.com

2 PhD in Animal Science, UEL, Londrina, PR, Brazil. E-mail: geisi_guerra@hotmail.com

3 Professor Senior, PhD, Graduate Program in Animal Science, UEL, Londrina, PR, Brazil. E-mail: mizubuti@uel.br

${ }^{4}$ Professors, PhD's, Zootechnical Department, UEL, PR, Brazil. E-mail: fabcastro76@yahoo.com.br; sgalbeiro@uel.br; angelapovedaparra@hotmail.com

${ }_{5}$ Professors, PhD's, Graduate Program in Animal Science, UEL, Londrina, PR, Brazil. E-mail: odimari@uel.br; jrbumbieris@ uel.br

${ }^{6}$ Professors, PhD's, Master's Degree in Animal Health and Production, Pitagoras University North of Parana, UNOPAR, Arapongas, PR, Brazil. E-mail: s.pertile@zootecnista.com.br; fabiola.cristine@kroton.com.br

* Author for correspondence
\end{abstract}

Received: July 07, 2020 - Approved: Nov. 25, 2020 
values to spectral data. The coefficients of determination $\left(R^{2}\right)$ were $0.74,0.85,0.98,0.75,0.85,0.71,0.82$, 0.77 , and 0.93 , and the ratio of performance deviations (RPD) obtained were 1.99, 2.71, 6.46, 2.05, 2.58, 3.84, 1.86, 2.35, 2.09, and 3.84 for ODS, MM, CP, NDF, ADF, ADL, CEL, HEM, and IVDMD, respectively. The prediction models obtained, in general, were considered to be of excellent quality, and demonstrated that the determination of the chemical composition of Tifton 85 grass can be performed using NIRS technology, replacing conventional analysis.

Key words: Cynodon spp. Hay. Leaf blade. NIRS. Protein.

\section{Resumo}

A redução da qualidade, do consumo e da digestibilidade da forragem pode ocasionar a diminuição do desempenho animal, resultando em prejuízos ao produtor rural. Desta forma, é importante monitorar essas características em plantas forrageiras para definir estratégias ou práticas que otimizem os sistemas de produção. Objetivou-se desenvolver e validar modelos de predição pela espectroscopia de infravermelho próximo (NIRS), para determinar a composição química do capim Tifton 85 (Cynodon spp.). Foram utilizadas amostras de capim verde (planta inteira, lâmina foliar, colmo + bainha e material senescente) e de feno, da mesma gramínea, totalizando 105 amostras. As amostras foram submetidas a análise química convencional para determinação dos teores de amostra seca em estufa (ASE), matéria mineral (MM), proteína bruta (PB), fibra em detergente neutro (FDN), fibra em detergente ácido (FDA), lignina em detergente ácido (LDA), celulose (CEL), hemicelulose (HEM) e digestibilidade in vitro da matéria seca (DIVMS). Posteriormente, todas as amostras foram escaneadas em espectrômetro Vis-NIR, para a coleta dos dados espectrais. Aplicouse a análise de componentes principais (PCA) ao conjunto de amostras, e utilizou-se a regressão por mínimos quadrados parciais modificadas para correlacionar valores de referência aos dados espectrais. Os coeficientes de determinação $\left(R^{2}\right)$ foram de 0,$74 ; 0,85 ; 0,98 ; 0,75 ; 0,85 ; 0,71 ; 0,82,0,77$ e 0,93 e as taxas de desvio de performance (RPD) de 1,99; 2,71; 6,46; 2,05; 2,58; 3,84; 1,86; 2,35; 2,09 e 3,84 para ASE, MM, PB, FDN, FDA, LDA, CEL, HEM e DIVMS respectivamente, na etapa de validação. Os modelos de predição obtidos, em geral, foram considerados de boa qualidade, e demonstraram que a determinação da composição química do Tifton 85 pode ser realizada pela tecnologia NIRS, em substituição à análise convencional.

Palavras-chave: Cynodon spp. Feno. Lâmina foliar. NIRS. Proteína.

\section{Introduction}

The production of Brazilian beef is mainly performed with the use of pastures. It is essential to monitor the nutritional composition of the plants, and conventional chemical analyses are performed for this. One of the most used perennial grasses in Brazil is Tifton 85 grass (Cynodon spp.), which is notable for its high nutritional quality and high forage production (Fonseca \& Martuscello,
2010). This grass can be used for grazing or in the form of hay, a strategy used in times of forage shortages, combined with monitoring of the chemical composition and changes related to the quality of the food.

Conventional chemical analysis, despite its standardization and worldwide acceptance, requires considerable time to perform, involves high operational costs with reagents and equipment, and results in the 
inconvenience of environmental pollution, owing to the incorrect disposal of the analysis residues (Almeida et al., 2018). It is in fact recognized that this disposal must be conducted safely, so there is no contamination of water and soil. Chemical analysis with the use of reagents can also cause harm to laboratory technicians, who are routinely exposed to toxic and harmful components.

With the advancement of technology used in agricultural production, there is a need to update methods and techniques applied in production systems. Modeling applied to food analysis for animal nutrition is being used increasingly, such as the development of models of prediction of nutritional composition of forage plants using the near-infrared spectroscopy (NIRS) methodology with the aid of chemometric software. Chemometrics employs statistical and mathematical methods to correlate the chemical or physical properties of the material in question with analytical data (Lohumi, Lee, Lee, \& Cho, 2015), represented by the electromagnetic information obtained using NIRS technology, thus enabling its use in chemical-bromatological analyses.

The NIRS methodology has been treated as an alternative to conventional chemical analysis because it does not use chemical reagents, has lower operational cost, and allows a wide analysis of food quickly, accurately, and without destruction of the sample (Deepa et al., 2016). The methodology is based on the interaction of near-infrared electromagnetic waves with a given sample, thus allowing the quantitative and qualitative evaluation of its constituents (Muñiz, Magalhães, Carneiro, \& Viana, 2012).

The development of global calibration models or equations that establish the relationship between the laboratory reference values and the spectral data obtained by NIR absorption is a commonly used approach (Andueza, Picard, Martin-Rosset, \& Aufrère, 2016). It is important to emphasize that the success of the calibration step depends on the correct execution of the reference analyses to minimize any type of error that may affect the predictions made by the models developed (Kragten \& Wyss, 2014). Calibration is the first stage performed to predict the nutritional value of forage using the NIRS methodology. The validation stage is then performed, which assesses the accuracy of the developed model and aims to ensure its credibility.

Thus, the present study aimed to develop prediction models for the chemical composition of Tifton 85 grass using NIRS.

\section{Material and Methods}

In June 2017, 105 samples of Tifton 85 grass (Cynodon spp.), cultivated on a property in the municipality of Arapongas, PR, were collected. The municipality is located at an altitude of $816 \mathrm{~m}$, and the average annual temperature varies from 20.0 to 21.0 ${ }^{\circ} \mathrm{C}$, presenting the $\mathrm{Cfa}$ climate classification according to Köppen. The average annual rainfall varies from 1600 to $1800 \mathrm{~mm}$, with January and December being the months with the highest rainfall volume (Nitsche, Caramori, Ricce, \& Pinto, 2019). Roofing fertilization was performed with $25 \mathrm{~kg} \mathrm{ha}^{-1}$ of urea 2 months before cutting. The experimental area had no irrigation system.

Twenty-one plots of $4 \mathrm{~m}^{2}$ each of Tifton 85 grass were used, duly delimited and identified. The grass was cut at 105 days of regrowth with a costal grass trimmer, 
maintaining a residue height of $5 \mathrm{~cm}$ above the soil. After cutting, we sampled approximately $500 \mathrm{~g}$ of grass from each plot for further analysis (whole plant and for morphological separation), and the rest of the material was placed on the plot for dehydration. After $72 \mathrm{~h}$ of cutting, when the grass reached the point of hay, a sample of approximately $500 \mathrm{~g}$ was collected for further analysis. The collected material was sent to the Bromatology Laboratory of the Pitágoras UNOPAR University - Campus Arapongas, for morphological separation of the samples and subsequent laboratory analyses.

A portion of the samples of green grass, approximately 60\%, was subjected to morphological separation into the leaf blade (LB), stem + sheath (SS), and senescent material (SEN). After separation, samples of the morphological components and whole plant of the grass were dehydrated in the drying oven with forced air circulation at $55^{\circ} \mathrm{C}$ $\left( \pm 5^{\circ} \mathrm{C}\right.$ ) for $72 \mathrm{~h}$. Then, the samples of grass and its morphological and hay components were ground in a Willey-type mill with a $1 \mathrm{~mm}$ sieve, and the content of oven-dried samples was determined at $105{ }^{\circ} \mathrm{C}$ (ODS), that of mineral matter (MM) in a muffle furnace at $600{ }^{\circ} \mathrm{C}$ and of crude protein (CP) using the Kjeldhal method (Detmann et al., 2012).

Analyses of fibrous fractions and in vitro dry matter digestibility (IVDMD) were performed at the Animal Nutrition Laboratory of the State University of Londrina. The determination of neutral (NDF) and acid (ADF) detergent fiber in an autoclave, and acid detergent lignin (ADL) with $72 \%$ sulfuric acid were performed sequentially (Detmann et al., 2012), using bags of non-woven fabric (NW100). Sodium sulfite was used in the NDF analysis. Hemicellulose (HEM) was estimated by the difference between NDF and ADF, and cellulose (CEL) by the difference between ADF and ADL (Van Soest, Robertson, \& Lewis, 1991).

The IVDMD of the samples was determined using the technique developed by Tilley and Terry (1963). The samples were packaged in NW40 bags and incubated with ruminal inoculum at $39^{\circ} \mathrm{C}$ for $48 \mathrm{~h}$ in an artificial incubator (TE-421) with agitation at $80 \mathrm{rpm}$. The ruminal fluid used as inoculum was obtained from a slaughterhouse from slaughtered cattle reared in pasture.

All the results obtained in the chemical analyses and IVDMD are presented as a percentage of dry matter to facilitate their use in the development of calibration and validation models using the NIRS methodology.

The 105 samples obtained (21 each of whole plant samples of grass, LB, SS, SEN, and hay) from the Tifton 85 grass were sent to the Agricultural Research Support Laboratory (LAPA) of the State University of Londrina for spectral analysis. The samples were homogenized, packaged in specific cuvettes, and scanned in a Vis-NIR spectrometer (Foss NIRSystems XDS; Silver Spring, MD, USA) with a reflectance band between 400 and $2500 \mathrm{~nm}$ to produce the composite spectra. Each sample was scanned three times, thus generating 315 spectra, to increase the digitized surface of the samples and reduce errors that may affect the prediction model (Yang et al., 2017).

The Kennard and Stone (1969) algorithm was used to separate the database during calibration and validation, creating independent sample subsets. A subset with 210 spectra was used for model development for calibration, and another subset with the remaining 105 spectra was used for validation. Thus, the same source database was used for both calibration and validation, but without 
using the same samples at each stage. Therefore, the calibration developed was validated with the initially excluded samples (Agelet \& Hurburgh, 2010). Thus, of the total sample set, $2 / 3$ was used to perform the calibration and $1 / 3$ to validate the models.

The spectral data were converted into logarithms of the inverse reflectance [log (1/R)] and analyzed using The Unscrambler X, v.10.3 (Camo Software ASA, Oslo, Norway). Principal component analysis (PCA) was applied to the set of samples to reduce the data dimension of the sample set and facilitate the interpretation of these data.

To correlate the reference values obtained from conventional chemical analyses to the spectral data of the calibration set, we used modified partial least squares regression (Shenk \& Westerhaus, 1991). The samples considered as outliers were removed at the time of prediction model development. These outliers were selected visually and manually, considering the samples that altered or deviated from the trend line in relation to the reference values and predicted values, according to the procedure described by Roussel (2015).

To construct the graph of mean spectra, the spectral values of the reading of each sample were used, considering the average of the values of each structure and type of forage (LB, SS, SEN, whole plant of grass, and hay).

Before the calibration stage, the spectra were subjected to mathematical pretreatments for correction of light dispersion, noise removal, and baseline correction, such as the 1st and 2nd derivative Savitzky-Golay smoothing with a window ranging from 1 to 15 points, and the standard normal variation transformation.
The efficiency of the calibration and validation models was evaluated using statistical parameters such as the standard error of calibration (SEC) and prediction (SEP) and the calibration and validation determination coefficients $\left(R^{2}\right)$, and the calibration and validation ratio of performance deviation (RPD), calibration and validation range error ratio (RER), and the optimal number of factors (N) were used for model development. The RPD was calculated as the ratio between the standard deviation and the value of either SEC or SEP (P. C. Williams \& Sobering, 1993). The RER was calculated by dividing the amplitude of the concentration range of the analytical data by either SEC or SEP (P. C. Williams \& Sobering, 1996). For standard errors, we considered those with SEP values 1.3 times higher, at most, than the SEC values (Windham, Mertens, \& Barton, 1989). The optimal number of factors in the development of the models was selected based on the response of greater variance and by the lowest mean error square root value (Gontijo Neto, Simeone, \& Guimarães, 2012).

\section{Results and Discussion}

Considerable variability was observed in the chemical composition of Tifton 85 grass (Table 1). IVDMD and the levels of ADF, CEL, HEM, NDF, and CP showed the largest variations, with amplitudes of $37 \%, 24 \%$, $21 \%, 20 \%, 15 \%$, and $13 \%$, respectively. This variability occurred owing to the different proportions of the plant that were analyzed as samples of LB, SS, and SEN, in addition to the whole plant of grass and hay, thus, creating a wide set of values. Variations of this type are a positive factor in the calibration using NIRS to predict the chemical composition of 
different forages (Lobos, Gou, Hube, Saldaña, \& Alfaro, 2013). It is important to note that higher NDF content, such as those found in the SS, SEN, and hay fractions (Table 2), can negatively influence the nutritional value of these fractions owing to higher amounts of cell wall compounds such as CEL, HEM, lignin, and insoluble protein (Van Soest, 1994). In contrast, the components of cellular content, such as soluble carbohydrates and $\mathrm{CP}$, are present in greater quantities in LF and whole grass plants (Table 2), which increases the quality of this fraction.

\section{Table 1}

Descriptive analysis of the chemical composition (\% of dry matter) of Tifton 85 grass (Cynodon spp.) determined using conventional chemical analysis (reference methods)

\begin{tabular}{|ccccc|}
\hline Variable & Minimum (\%) & Mean (\%) & Maximum (\%) & SD (\%) \\
\hline DM (\%) & 30.07 & 43.37 & 75.59 & 13.49 \\
\hline ODS (\%) & 87.84 & 93.59 & 97.09 & 1.86 \\
\hline MM (\%) & 5.62 & 8.03 & 10.00 & 0.97 \\
\hline CP (\%) & 4.18 & 9.61 & 17.29 & 3.23 \\
\hline NDF (\%) & 64.92 & 71.72 & 79.74 & 3.01 \\
\hline ADF (\%) & 23.93 & 34.63 & 48.40 & 4.59 \\
\hline ADL (\%) & 0.75 & 3.54 & 6.60 & 1.32 \\
\hline CEL (\%) & 22.69 & 31.08 & 43.83 & 3.62 \\
\hline HEM (\%) & 26.75 & 37.08 & 47.06 & 4.52 \\
\hline IVDMD (\%) & 43.90 & 64.48 & 80.83 & 8.67 \\
\hline
\end{tabular}

$\mathrm{DM}$, dry matter; ODS, oven dried sample; $\mathrm{MM}$, mineral matter; $\mathrm{CP}$, crude protein; NDF, neutral detergent fiber; $A D F$, acid detergent fiber; $A D L$, acid detergent lignin; CEL, cellulose; HEM, hemicellulose; IVDMD, in vitro dry matter digestibility; $\mathrm{SD}$, standard deviation.

Figure 1 shows the mean spectra resulting from the set of samples of LB, SS, SEN, green grass, and hay. The observed behavior was characterized by different levels of absorbance according to the analyzed group. The samples of grass and hay showed spectral similarity, represented by the overlapping lines, possibly because the main difference between these samples was the process of haymaking, thus demonstrating a similar chemical composition. There was a small numerical difference between these two materials only for NDF and IVDMD (Table 2), in which the drying process increased the NDF and reduced the IVDMD of the hay. 
Table 2

Chemical composition (\% of dry matter) of the whole plant, hay, and morphological components of Tifton 85 grass (Cynodon spp.)

\begin{tabular}{|cccccc|}
\hline Variable & Whole plant & LB & SS & SEN & Hay \\
\hline ODS (\%) & 95.23 & 93.92 & 94.05 & 93.98 & 90.73 \\
\hline MM (\%) & 8.08 & 8.86 & 7.01 & 8.19 & 8.02 \\
\hline CP (\%) & 9.39 & 14.96 & 6.80 & 6.61 & 10.28 \\
\hline NDF (\%) & 68.91 & 69.65 & 71.64 & 75.51 & 72.88 \\
\hline ADF (\%) & 37.65 & 27.13 & 33.96 & 36.19 & 38.20 \\
\hline ADL (\%) & 4.37 & 1.57 & 3.74 & 3.82 & 4.23 \\
\hline CEL (\%) & 33.28 & 25.56 & 30.22 & 32.36 & 33.97 \\
\hline HEM (\%) & 31.25 & 42.50 & 37.67 & 39.32 & 34.67 \\
\hline IVDMD (\%) & 70.25 & 73.48 & 64.60 & 50.10 & 63.98 \\
\hline
\end{tabular}

$\mathrm{LB}$, leaf blade; $\mathrm{SS}$, stem + sheath; $\mathrm{SEN}$, senescent material; ODS, oven dried sample; $\mathrm{MM}$, mineral matter; $\mathrm{CP}$, crude protein; $N D F$, neutral detergent fiber; $A D F$, acid detergent fiber; $A D L$, acid detergent lignin; $C E L$, cellulose; HEM, hemicellulose; IVDMD, in vitro dry matter digestibility.

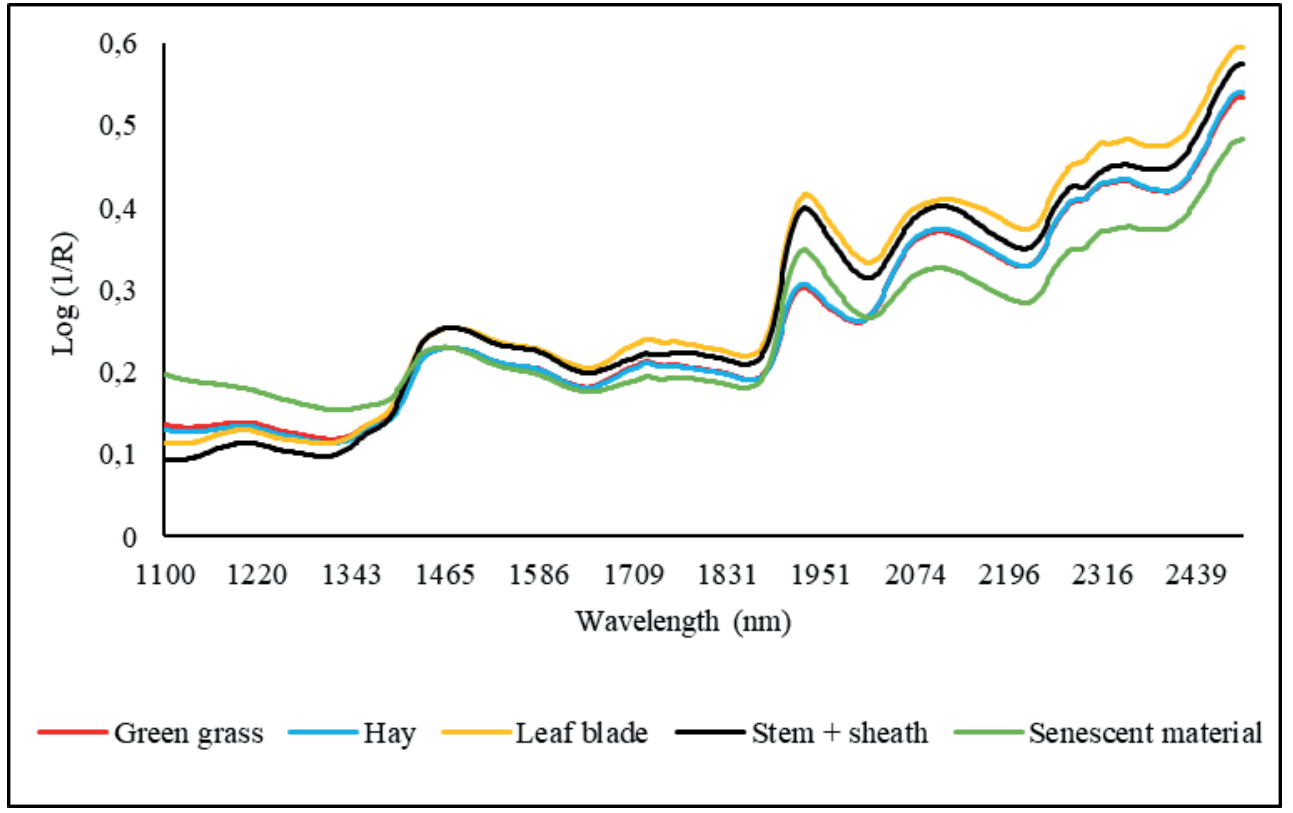

Figure 1. Absorbance of mean spectra of different samples of Tifton 85 grass (Cynodon spp.). 
The spectra obtained from the LB and SS samples showed a greater distinction in the absorbance between the structures, which may be linked to the amount of cellular content components, that is, the best chemical composition of the samples with respect to LB (Table 2). The LB samples presented greater absorbance than the other morphological components, mainly in peaks around 1900, 2100, and $2300 \mathrm{~nm}$, which although containing low fiber content, presented these high peaks. However, the presentation of these peaks is mainly owing to the $\mathrm{N}-\mathrm{H}$ bonds that characterize protein molecules (Guerra, 2019; Schwanninger, Rodrigues, \& Fackler, 2011) and the digestibility of the samples (Decruyenaere et al., 2009). A spectral band overlay found at approximately $1450 \mathrm{~nm}$ may characterize the absorption region associated with an $\mathrm{O}-\mathrm{H}$ (water) harmonic transaction (Arzani, Sanaei, Barker, Ghafari, \& Motamedi, 2015).
Regarding the representative spectra of SEN samples, these differed the most from the other sample groups, with lower absorbance (spectral range approximately 1465-1831 and 2000-2439 nm), probably because of the low digestibility of this morphological component. According to Decruyenaere et al. (2009), there is greater absorbance in samples with better digestibility. In this study, the LF samples presented better IVDMD, and consequently, greater absorbance in relation to the samples of SEN.

Figure 2 illustrates the spectral variability according to the PCA related to the spectra of Tifton 85 samples. From the three principal components that were used to construct the models, two components corresponded to $96 \%$ of the data variability, of which $82 \%$ was explained by component 1 (CP 1) and $14 \%$ by component 2 (CP 2).

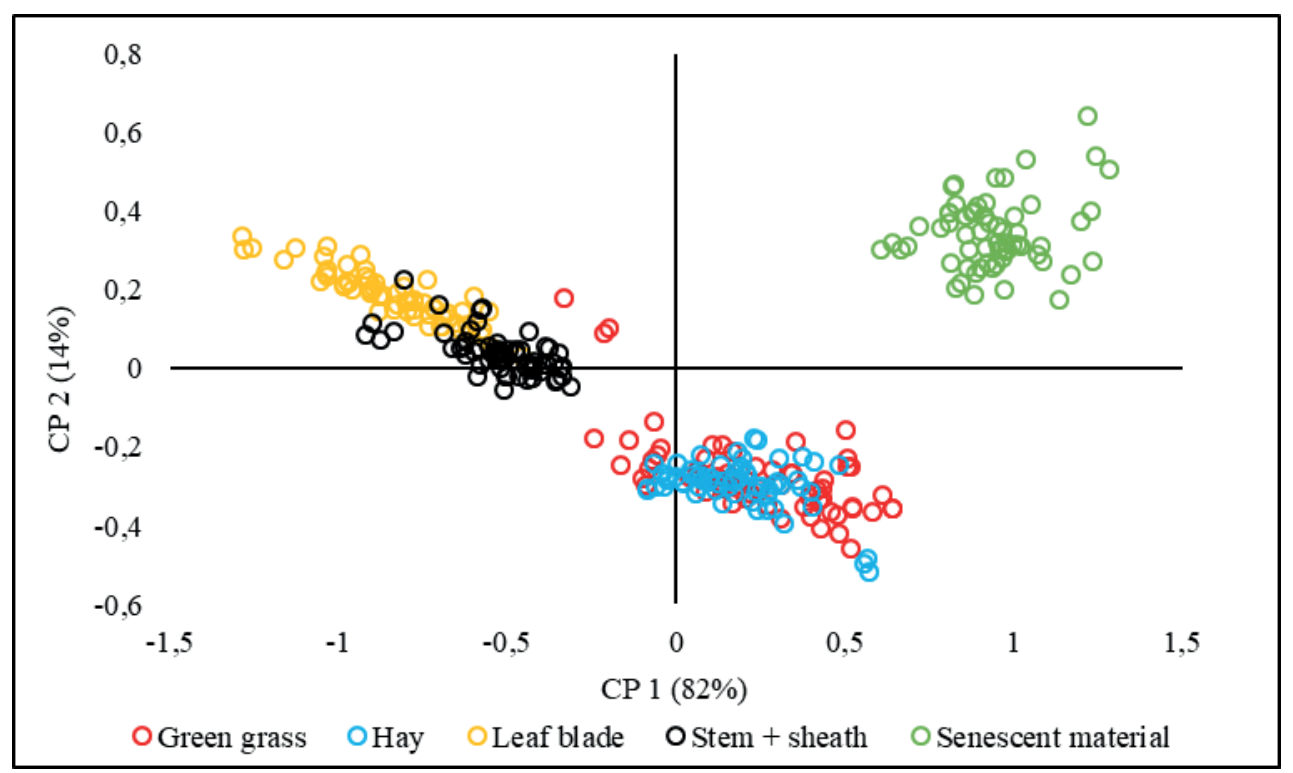

Figure 2. Principal components analysis (PCA) of the samples grouped according to the type of roughage and morphological components of the forage. 
In addition, Figure 2 shows the formation of possible groups, according to the type of roughage (grass and hay) and morphological components (LB, SS, and SEN). This separation also shows the similarities in the chemical composition between the groups, such as grass and hay, and greater discrepancy in SEN confirming the differences in nutritional value observed among these materials as shown in Table 2. The considerable levels of the fibrous fraction components in the SEN samples associated with their lower absorbance were evidenced in the formation of this group in the PCA (Figure 2). Considering the whole plant samples of grass and hay, as mentioned above, because they correspond to the same source material, they differed only in the values of NDF and IVDMD and showed similar absorbance. In relation to the LB and SS samples, their distribution in the graph was probably also influenced by the higher degree of absorbance of the cellular components present in the leaves, which have a better bromatological composition.

In the calibration stage, results of $\mathrm{R}^{2}$ equal to or above 0.70 were obtained, with the lowest value observed for ADL (0.70) and the highest value for BP (0.96), and an RPD greater than 2.5 for the variables MM, CP, and IVDMD (Table 3 ). The validation results for the MM, CP, ADF, CEL, and IVDMD models presented R2 values greater than 0.80 and RPD greater than 2.5 for MM, CP, and IVDMD (Figure 3). Calibration errors were similar to the errors in the validation step, indicating good accuracy between the results obtained from conventional chemical analyses and those from near-infrared spectroscopy.

\section{Table 3}

Calibration parameters of the prediction models to determine the nutritional composition of Tifton 85 grass (Cynodon spp.)

\begin{tabular}{|ccccccccc|}
\hline Variable & $\begin{array}{c}\text { Mathematical } \\
\text { pre-treatment }\end{array}$ & $\mathrm{n}$ & Mean (\%) & SEC (\%) & $R^{2}$ & RPD & RER & $\mathrm{N}$ \\
\hline ODS (\%) & SG 129 & 198 & 93.51 & 0.86 & 0.78 & 2.13 & 10.76 & 7 \\
\hline MM (\%) & SG 129 & 205 & 8.09 & 0.38 & 0.84 & 2.50 & 11.53 & 6 \\
\hline CP (\%) & SG 1215 & 209 & 9.61 & 0.60 & 0.96 & 5.28 & 21.85 & 5 \\
\hline NDF (\%) & SG 129 & 203 & 71.66 & 1.34 & 0.80 & 2.26 & 11.06 & 6 \\
\hline ADF (\%) & - & 199 & 34.55 & 2.05 & 0.80 & 2.20 & 9.20 & 5 \\
\hline ADL (\%) & SG 1215 & 199 & 3.49 & 0.71 & 0.70 & 1.82 & 7.35 & 6 \\
\hline CEL (\%) & - & 201 & 31.01 & 1.67 & 0.77 & 2.07 & 8.66 & 6 \\
\hline HEM (\%) & SNV & 193 & 37.13 & 2.09 & 0.78 & 2.12 & 8.26 & 5 \\
\hline IVDMD (\%) & SG 129 & 202 & 64.04 & 2.31 & 0.93 & 3.69 & 13.87 & 6 \\
\hline
\end{tabular}

LB, leaf blade; SS, stem + sheath; SEN, senescent material; ODS, oven dried sample; MM, mineral matter; $C P$, crude protein; NDF, neutral detergent fiber; $A D F$, acid detergent fiber; $A D L$, acid detergent lignin; $C E L$, cellulose; HEM, hemicellulose; IVDMD, in vitro dry matter digestibility; $\mathrm{SEC}$, standard error of calibration; $R^{2}$, coefficient of determination of calibration; RPD, ratio of performance deviation; RER, range error ratio; N, number of factors used in model development.

Mathematical pre-treatments - SG 129, Savitzky-Golay: $1^{\text {a }}$ derivative, $2^{\circ}$ degree polynomial, smoothing 9; SG 1215 , Savitzky-Golay: $1^{\text {a }}$ derivative, $2^{\circ}$ degree polynomial, smoothing 15 ; SNV, standard normal variance transformation; without the use of mathematical pre-treatment. 

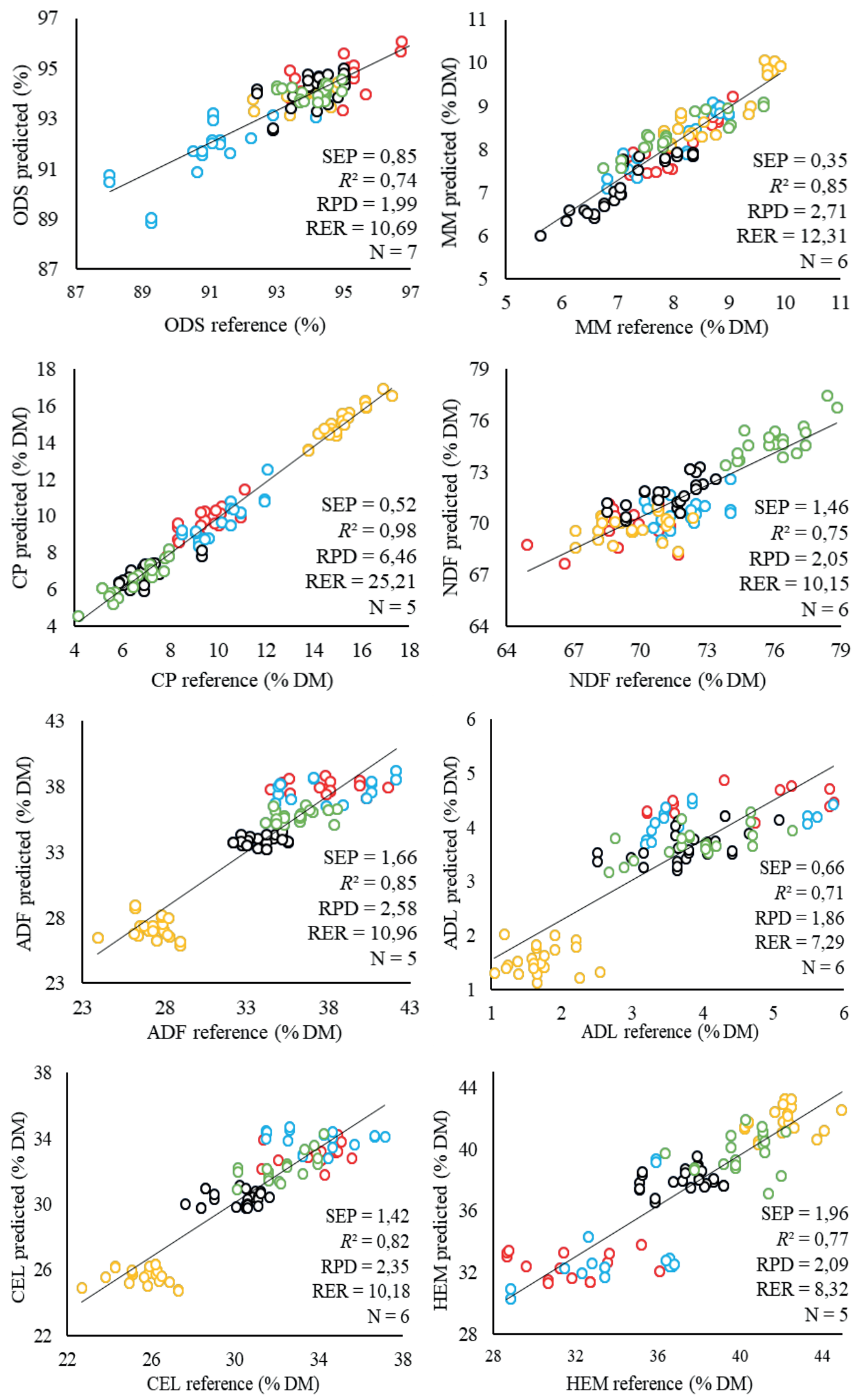


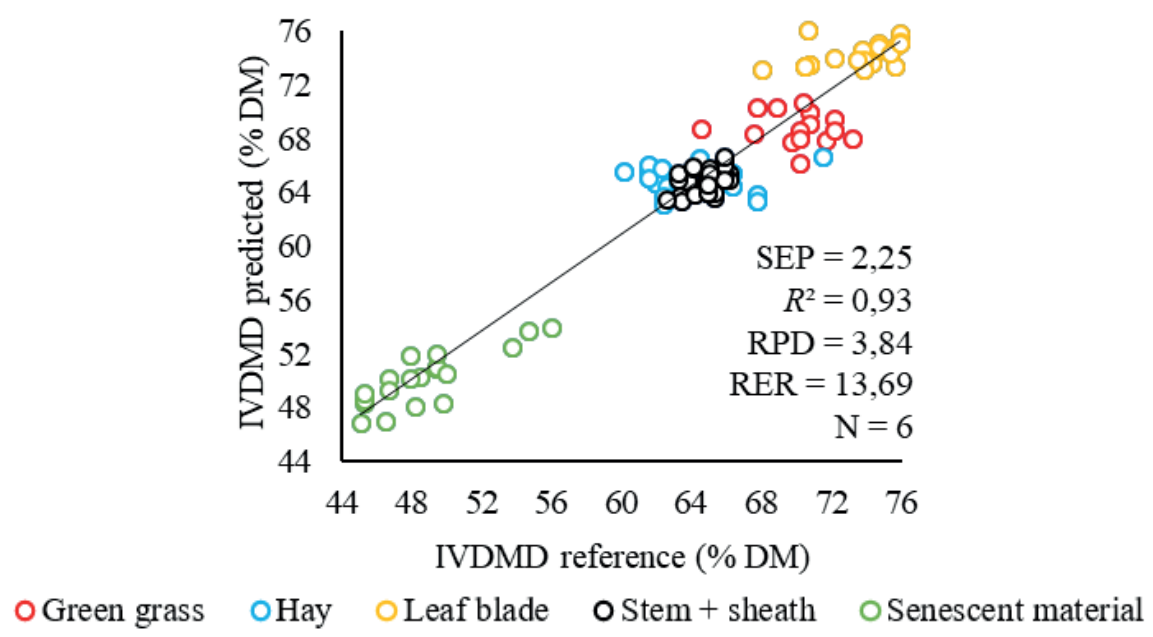

Figure 2. Validation of the prediction models for chemical composition and in vitro dry matter digestibility of Tifton 85 grass (Cynodon spp.).

ODS, oven dried sample; $M M$, mineral matter; $C P$, crude protein; NDF, neutral detergent fiber; ADF, acid detergent fiber; $A D L$, acid detergent lignin; $C E L$, cellulose; HEM, hemicellulose; IVDMD, in vitro dry matter digestibility; DM, dry matter, SEP, standard error of prediction; $R^{2}$, coefficient of determination of prediction; RPD, ratio of performance deviation; RER, range error ratio; $N$, number of factors used in model development.

The statistical parameters used to evaluate the models should be analyzed together so that there is reliability in the interpretation and the potential for future use. The $R^{2}$ values are used to evaluate the accuracy of these models; $R^{2}$ values above 0.80 indicate a model quality considered satisfactory to good, and $R^{2}$ values above 0.90 are considered excellent (Tran et al., 2010). Associated with these high $R^{2}$ values, the values related to standard errors determine the accuracy and robustness of the model. The SEP must be small and at most 1.3 times greater than that of the SEC (Windham et al., 1989). The evaluation of the model using SEP is important because of its relationship with the reference laboratory analyses, which should be performed well. High SEP values may represent factors related to the physical and chemical composition of the samples, and very low values may indicate homogeneity of the samples used in the calibration (Kragten \& Wyss, 2014).

Regarding the RPD, which evaluates the predictive capacity of the developed model, P. C. Williams and Sobering (1996) considered 2.5 as the minimum value. Goldshleger, Chudnovsky and Ben-Binyam (2013) classified the models according to RPD values considering values below 1.5 as unusable; those between 1.5 and 2.0 as usable for the distinction between models of high and low predictability; those between 2.0 and 2.5 as models with the possibility of quantitative prediction; and those between 2.5 and 3.0 or above 3.0, as models of excellent predictive ability. Very low RPD values (approximately 1.0) demonstrate that the SEP value and sample standard deviation are the same, and thus, the prediction is compromised (P. C. Williams \& Sobering, 1993). To evaluate the practical 
usefulness and accuracy of a predictive model, one can use the RER that must have values above 10 (P. C. Williams \& Sobering, 1996). Combining values of RPD greater than 3 and RER greater than 10, there is an indication of a good prediction for quantitative analyses ( $P$. Williams, 2014).

The set of results of the validation stage was used for the general evaluation of the models (Figure 3), using $R^{2}$ and SEC/SEP values to evaluate accuracy and precision respectively. The number of optimal factors for the development of the models presented values between 5 and 7 , remaining at the recommended limit of 6 to 8 factors. When this number is too high or low, it may contain noise and validation failures or not be enough for modeling (Williams, Dardenne \& Flinn, 2017).

The best proposed models of the analyzed database were for CP $\left(R^{2}=0.98\right.$, $\mathrm{RPD}=6.46$ and RER $=25.21, \mathrm{~N}=5$ ) and IVDMD $\left(R^{2}=0.93, \mathrm{RPD}=3.84\right.$ and $\mathrm{RER}=13.69, \mathrm{~N}=$ 6). The constitution of the protein's chemical structure favors the prediction of this nutrient using the NIRS methodology, as the molecules of carbon, hydrogen, oxygen, and nitrogen that make up the protein molecule present a large number of bonds, such as those of N-H (Guerra, 2019; Oliveira, 2017), which absorb more irradiated light, providing better detection of absorbance bands. Therefore, good models were generated, corroborating the information described by Gontijo Neto et al. (2012), Lobos et al. (2013), and Guerra (2019), where evaluation of tropical and temperate forages was performed, and the $R^{2}$ values obtained were above 0.90 associated with low error values, which indicates good accuracy and precision of the models.
Considering the prediction of IVDMD by NIRS, it should be noted that there is a dependence related to the protein and fibrous content of the analyzed sample (Guerra, 2019). Therefore, IVDMD can be successfully predicted from the chemical composition of the samples, even though there is no direct relationship with the vibrational energy of the molecules that are normally detected by the NIRS methodology (Roberts, Stuth, \& Flinn, 2004). The most striking spectral regions in the development of the model were near the wavelengths of $1370,1700,1750,2002$, and $2300 \mathrm{~nm}$, with the presence of $\mathrm{O}-\mathrm{H}, \mathrm{C}-\mathrm{O}, \mathrm{C}-\mathrm{H}$, $\mathrm{N}-\mathrm{H}$ bonds that can be related to fiber and protein content.

The prediction model developed for ODS was considered adequate $\left(R^{2}=0.74\right.$, RPD $=1.99$ and RER = 10.69, $\mathrm{N}=7$ ), according to the classification of these parameters by Goldshleger et al. (2013), Tran et al. (2010) and P. C. Williams \& Sobering (1996). Possibly, to improve the quality of this model, the inclusion of more samples would be useful.

Good results were obtained in the development of the MM prediction model $\left(R^{2}=\right.$ 0.85, RPD = 2.71 and RER = 12.31, N = 6), which can be explained by the formation of complexes between minerals and organic molecules present in the samples, enabling the detection of absorption bands in the near-infrared region (Roberts et al., 2004) (Figure 3). The occurrence of these complexes is important, as the prediction of the mineral portion of forage plants may be underestimated by the fact that saline and ionic forms do not have energy absorption in the near-infrared region (Shenk \& Westerhaus, 1994).

Among the models related to the fibrous portion, it was observed that the ADF 
model presented the best results $\left(R^{2}=0.85\right.$, RPD $=2.58$ and RER = 10.96, $N=5$ ), whereas for NDF, CEL, and HEM, the models can be considered of satisfactory quality (Figure 3). The spectral ranges for creating the models were 1100-2448 nm for ADF, 1108-2472 $\mathrm{nm}$ for NDF, 1100-2464 $\mathrm{nm}$ for CEL, and 1100-2248 nm for HEM. The prediction of the fibrous fraction of tropical grasses can often be compromised owing to its biochemical complexity (Molano, Cortés, Ávila, Martens, \& Muñoz, 2016). In general, this fraction comprises different chemical groups involving different spectral regions as well as the relation between the spectrum and the reference method (Brogna et al., 2018). For ADL content prediction, the model developed (spectral range 1114-2466 $\mathrm{nm}$ ) presented lower quality $\left(R^{2}=0.71, \mathrm{RPD}=1.86\right.$ and RER $\left.=7.29, \mathrm{~N}=6\right)$ and could only be used to distinguish high and low values (Goldshleger et al., 2013). This can be explained by the fact that this is a complex polymer and laborious quantification involving several stages of analysis and is considered a component indigestible to animals (Guerra, 2019; Van Soest, 1994).

In the distribution graph (Figure 3), it was possible to observe that the best models obtained for CP and IVDMD represented the nutrient dynamics in each group of samples analyzed in relation to the roughage type and morphological component. These graphs show that the analyzed data are well distributed and adjusted to the trend line, with the samples comprising the confidence interval (Fekadu et al., 2010) and characterized according to the chemical composition, which can be observed in the present study.

In the validation of the prediction models of the variables $\mathrm{CP}$ and IVDMD, there was a linear behavior well-adjusted to the trend line. For the $\mathrm{CP}$ prediction model, it was verified that the data were distributed according to the chemical composition, and the LB samples presented high CP content, and the SS and SEN samples presented the lowest CP content. Green grass and hay showed intermediate values. In the prediction models of IVDMD, it was observed that the data distribution was also in accordance with the digestibility percentage. There was greater digestibility in LB and green grass samples, and lower digestibility in SEN. The SS and hay samples presented intermediate values. Therefore, for both variables, CP and IVDMD, there was a linear behavior; however, the profile of variation in CP content between the types of material (grass and hay) and the morphological components differed from those presented by the IVDMD models.

As for the models developed for NDF, CEL, and HEM, which presented satisfactory quality, it was possible to verify in the distribution graphs that the behavior of the samples in relation to the trend line was more dispersed, as in the case of ADL. This indicates that including more samples into the database could be an adjustment solution for these models.

The results obtained with the prediction models developed indicate the possibility of the practical application of these models in the analysis of the chemical composition of grass and hay from Tifton 85 . It is important to point out that to ensure the success of these models, one must test them with more samples of the same grass. Therefore, it is suggested that the prediction models obtained in this study are tested with samples external to the models developed, and that they originate from other regions. 


\section{Conclusions}

The prediction models developed using NIRS for the determination of mineral matter, crude protein, acid detergent fiber and in vitro dry matter digestibility of Tifton 85 grass, have good accuracy and can be considered as an alternative to conventional chemical analysis of this grass. To further improve the accuracy of the models, it is suggested that more samples are included into the database with external samples from various regions.

\section{References}

Agelet, L. E., \& Hurburgh, C. R., Jr. (2010). A tutorial on Near Infrared Spectroscopy and its calibration. Critical Rewiews in Analytical Chemistry, 40(4), 246-260. doi: 10.1080/10408347.2010.515468

Almeida, M. T. C., Delphino, T. R., Paschoalotto, J. R., Carvalho, V. B., Perez, H. L., D'Aurea, E. M. O.,... Ezequiel, J. M. B. (2018). Predições da espectroscopia no infravermelho próximo podem determinar a digestibilidade e o consumo alimentar de cordeiros confinados. Arquivo Brasileiro de Medicina Veterinária e Zootecnia, 70(2), 597-605. doi: 10.1590/1678-4162-9548

Andueza, D., Picard, F., Marin-Rosset, W., \& Aufrère, J. (2016). Near-infrared Spectroscopy calibrations performed on over-dried green forages for the prediction of chemical composition and nutritive value of preserved forage for ruminants. Applied Spectroscopy, 70(8), 1321-1327. doi: 10.1177/000370281665 4056

Arzani, H., Sanaei, A., Barker, A. V., Ghafari, S., \& Motamedi, J. (2015). Estimating nitrogen and acid detergent fiber contents of grass species using Near Infrared Reflectance Spectroscopy (NIRS). Journal of Rangeland Science, 5(4), 260-268.

Brogna, N., Palmonari, A., Canestrari, G., Mammi, L., Dal Prà, A., \& Formigoni, A. (2018). Technical note: near infrared reflectance spectroscopy to predict fecal indigestible neutral detergent fiber for dairy cows. Journal of Dairy Science, 101(2), 1-6. doi: 10.3168/jds.2017-13319

Decruyenaere, V., Lecomte, P., Demarquilly, C., Aufrere, J., Dardenn, P., Stilmant, D., \& Buldgen, A. (2009). Evaluation of green forage intake and digestibility in ruminants using near infrared reflectance spectroscopy (NIRS): Developing a global calibration. Animal Feed Science Technology, 148(2-4), 138-156. doi: 10. 1016/j.anifeedsci.2008.03.007

Deepa, K., Senthilkumar, S., Kalpana, K., Suganya, T., Sasikimar, P., Thirumalaisamy, G.,... Vasanthakumar, P. (2016). NIRS in animal sciences. International Journal Science, 5(2), 605-610.

Detmann, E., Souza, M. A., Valadares, S. C., Fo., Queiroz, A. C., Berchielli, T. T., Saliba, E. O. S.,... Azevedo, J. A. G. (2012). Métodos para análise de alimentos. Visconde do Rio Branco, MG: UFV.

Fekadu, D., Bediye, S., Kehaliw, A., Daba, T., Kitaw, G., \& Assefa, G. (2010). Near Infrared Reflectance Spectroscopy (NIRS) for determination of chemical entities of natural pasture from Ethiopia. Agriculture and Biology Journal of North America, 1(5), 919-922. doi: 10.5251/ abjna.2010.1.5.919.922

Fonseca, D. M., \& Martuscello, J. A. (2010). Plantas forrageiras. Viçosa, MG: Ed. UFV. 
Goldshleger, N., Chudnovsky, A., \& BenBinyam, R. (2013). Predicting salinity in tomato using soil reflectance spectra. International Journal of Remote Sensing, 34(17), 6079-6093. doi: 10.1080/014311 61.2013 .793859

Gontijo Neto, M. M., Simeone, M. L. F., \& Guimarães, C. C. (2012). Predição do teor de proteína bruta em biomassa de capins braquiária por meio de espectroscopia NIR. (Comunicado Técnico, 205). Sete Lagoas: EMBRAPA.

Guerra, G. L. (2019). Espectroscopia de infravermelho próximo na avaliação da qualidade nutricional de Brachiaria brizantha cultivada em diferentes tipos de solo. Tese de doutorado, Universidade Estadual de Londrina, Londrina, PR Brasil. Recuperado de http://www. bibliotecadigital.uel.br

Kennard, R. W., \& Stone, L. A. (1969). Computer aided design of experiments. Technometrics, 11(1), 137-148. doi: 10.23 $07 / 1266770$

Kragten, S. A., \& Wyss, U. (2014). Les fourrages à la lumière de proche infrarouge (NIRS). Recherche Agronomique Suisse, 5(5), 204-211.

Lobos, I., Gou, P., Hube, R., Saldaña, R., \& Alfaro, M. (2013). Evaluation of potencial NIRS to predict pastures nutritive value. Journal of Soil Science and Plant Nutrition, 13(2), 463-468. doi: 10.4067/S0718-95162013 005000036

Lohumi, S., Lee, S., Lee, H., \& Cho, B. (2015). A review of vibrational spectroscopic techniques for the detection of food authenticity and adulteration. Trends in Food Science \& Technology, 46(1), 85-96. doi: 10.1016/j.tifs.2015.08.003
Molano, L. M., Cortés, M. L., Ávila, P., Martens, S. D., \& Muñoz, L. S. (2016). Ecuaciones de calibración en espectroscopía de reflectancia en el infrarrojo cercano (NIRS) para predicción de parámetros nutritivos en forrajes tropicales. Tropical Grasslands, 4(3), 106-107. doi: 10.17138/TGFT(4)139145

Muñiz, G. I. B., Magalhães, W. L. E., Carneiro, M. E., \& Viana, L. C. (2012). Fundamentos e estado da arte da espectroscopia no infravermelho próximo no setor de base florestal. Ciência Florestal, 22(4), 865-875. doi: 10.5902/198050987567

Nitsche, P. R., Caramori, P. H., Ricce, W. S., \& Pinto, L. F. D. (2019). Atlas climático do estado do Paraná. Londrina, PR: IAPAR. Recuperado de http://www.idrparana.pr. gov.br/Pagina/Atlas-Climatico

Oliveira, D. M. (2017). Análise de forragens por espectroscopia no infravermelho próximo, espectroscopia de emissão óptica em plasma induzido por laser e fusão de dados. Dissertação de mestrado, Universidade Estadual de Campinas, Campinas, SP, Brasil. Recuperado de http://repositorio.unicamp.br/jspui/ handle/REPOSIP/325383

Roberts, C. A., Stuth, J. W., \& Flinn, P. (2004). Near-infrared spectroscopy in agriculture. In C. A. Roberts, J. Workman Jr, \& J. B. Reeves III (Eds.), Analysis of forages and feedstuffs (pp. 231-267). Wisconsin, Wl: Madison.

Roussel, S. (2015). Formation: analyse de données spectroscopiques. Théorie et pratique sur the Unscrambler $X^{\circledR} .1329$. Montpellier: Cirad. 
Schwanninger, M., Rodrigues, J. C., \& Fackler, K. (2011). A review of band assignments in near infrared spectra of wood and wood components. Journal of Near Infrared Spectroscopy, 19(5), 287-308. doi: 10. 1255/jnirs.955

Shenk, J. S., \& Westerhaus, M. O. (1991). Population definition, sample selection, and calibration procedures for near infrared reflectance spectroscopy. Crop Science, 31(2), 469-474. doi: 10.2135/ cro psci1991.0011183Х003100020049x

Shenk, J. S., \& Westerhaus, M. O. (1994). Forage quality, evaluation, and utilization. In G. C. Fahey Jr. (Ed.), The application of near infrared reflectance spectroscopy (NIRS) to forage analysis (pp. 406-449). Wisconsin, WI: Madison.

Tilley, J. M. A., \& Terry, R. A. (1963). A twostage technique for the in vitro digestion of forage crop. Journal British Grassland Society, 18(2), 104-111. doi: 10.1111/ j.1365-2494.1963.tb00335.x

Tran, H., Salgado, P., Tillard, E., Dardenne, P., Nguyen, X. T., \& Lecomte, P. (2010). "Global" and "local" predictions of dairy diet nutritional quality using near infrared reflectance spectroscopy. Journal of Dairy Science, 93(10), 4961-4975. doi: 10.3168/jds.2008-1893

Van Soest, P. J. (1994). Lignin. In P. J. Van Soest (Ed.), Nutritional ecology of the ruminant (pp. 177-195). Ithaca, NY: Cornell University.

Van Soest, P. J., Robertson, J. B., \& Lewis, B. A. (1991). Methods for dietary, neutral detergent fiber, and nonstarch polysaccharides in relation to animal nutrition. Journal of Dairy Science, 74(10),
3583-3597. doi: 10.3168/jds.S0022-0302 (91)78551-2

Williams, P. (2014). The RPD statistic: a tutorial note. NIR News, 25(1), 22-23. doi: 10.1255/ nirn.1419

Williams, P., Dardenne, P., \& Flinn, P. (2017). Tutorial to be included in a report on a near infrared spectroscopy project. Journal of Near Infrared Spectroscopy, 25(2), 85-90. doi: 10.1177/0967033517702395

Williams, P. C., \& Sobering, D. C. (1993). Comparison of commercial near infrared transmittanceand reflectanceinstruments for analysis of whole grains and seeds. Journal of Near Infrared Spectroscopy, 1(1), 25-33. doi: 10.1255/jnirs.3

Williams, P. C., \& Sobering, D. C. (1996). How do we do it: a brief summary of the methods we use in developing nearinfrared calibrations. In A. M. C. Davies \& P. L. Williams (Eds.), Near infrared spectroscopy: the future waves (pp. 185188). Chichester, UK: NIR Publications.

Windham, W. R., Mertens, D. R., \& Barton, F. E. (1989). Protocol for NIRS calibration: sample selection and equation development and validation. In G. C. Marten, J. S. Shenk, \& F. E. Barton II (Eds.), Near infrared reflectance spectroscopy (NIRS): analysis of forage quality. (pp. 96-103). Washington, DC: USDA-ARS: Agricultural Handbook.

Yang, Z., Nie, G., Pan, L., Zhang, Y., Huang. L., Ma, X., \& Zhang, X. (2017). Development and validation of near-infrared spectroscopy for the prediction of forage quality parameters in Lolium multiforum. PeerJ Computer Science, 5(10), 1-20. doi: 10. 7717/peerj.3867 